\title{
Impact of Front Line Demonstrations of INM in Okra During Off Season in the Dang District of Gujarat
}

\author{
S. A. Aklade ${ }^{1 *}$, J. B. Dobariya² and N. M. Thesiya ${ }^{3}$
}

${ }^{1}$ Dept. of Horticulture, Polytechnic In Agriculture, NAU, Waghai, Dangs, Gujarat (396 450), India

${ }^{2}$ Ext. Education, ${ }^{3}$ Dept. of Agronomy, KVK, NAU, Waghai, Dangs, Gujarat, KVK, NAU, Waghai, Dangs, Gujarat (396 450), India

\section{Corresponding Author}

S. A. Aklade

e-mail: sandeepaklade@nau.in

\author{
Article History \\ Article ID: IJEP0257 \\ Received in $18^{\text {th }}$ June, 2018 \\ Received in revised form $25^{\text {th }}$ July, 2018 \\ Accepted in final form $17^{\text {th }}$ August, 2018
}

\begin{abstract}
Okra is the major vegetable crops grown in the Dang district of Gujarat state especially during the rabi season which can be consider as off season as okra is the main crop of kharif and summer season. One of the major constraints of low productivity of okra may be due to partial adoption of recommended package of practices by the growers. So, to address the yield gap, the front line demonstrations on integrated nutrient management (INM) along with scientific package of practices in okra were conducted for three consecutive years from 2012-13 to 2014-15 on farmer's field in different villages of the Dang district. Prevailing farmers' practices were treated as control for comparison with recommended practices. In the three years data, it was observed that due to adoption of INM along with scientific package of practices, average yield of $96.0 \mathrm{q} \mathrm{ha}^{-1}$ was obtained in demonstrated plot over $83.7 \mathrm{q} \mathrm{ha}^{-1}$ in control plots with an additional yield of $12.3 \mathrm{q} \mathrm{ha}{ }^{-1}$ and increasing the average productivity of okra by $14.8 \%$. The average extension and technology gap were found to be 11.0 and $24.0 \mathrm{q}$ ha ${ }^{-1}$, respectively with the technology index of $20.0 \%$ during the demonstration years. Besides this, the demonstrated plots gave higher gross return of $₹ 1,13,533.00 \mathrm{ha}^{-1}$, net return of $₹ 71,300.00 \mathrm{ha}^{-1}$ with higher benefit cost ratio of 2.69 as compared to farmer's practice during the three years of study.
\end{abstract}

Keywords: Okra, front line demonstrations, INM, yield, extension gap, technology gap

\section{Introduction}

Okra (Abelmoschus esculentus L. Moench) is an annual vegetable crop and generally grown in kharif and summer season as the climate is most suitable for its growth and development but in the Dangs it is largely cultivated during rabi season which is consider as off season for this crop. Even though the yield is somewhat less in rabi as comparable to other seasons the farmer's are getting higher returns within a short period of time. It is one of the important vegetable crop generally propagated by the seed and pods are good source of iron, iodine, vitamin A, B and C. Okra thrives in all kinds of soils, but it grows best in a friable well manured soil (Yawalkar and Ram, 2004). The major problems identified were inappropriate nutrient management, narrow spacing, higher seed rate per unit area, higher infestation of pest and diseases due to off season and forest area, etc. So, the demonstrations were conducted on INM with guidance on other crop management practices to increase the yield and returns of okra by imparting trainings, field visits, field days and diagnostic visits at farmer's fields.

\section{Materials and Methods}

The present study was carried out by Krishi Vigyan Kendra, Navsari Agricultural University, Waghai, District-Dangs, Gujarat state, India on integrated nutrient management (INM) in okra for three consecutive years viz. 2012-13, 2013-14 and 2014-15 during rabi season. Total 30 demonstrations in a 15 ha area were conducted on farmer's field and each frontline demonstration was laid out on 0.5 ha area while adjacent 0.5 ha was considered as control for comparison (farmer's practice). Dangs district comes under South Gujarat Heavy Rainfall Zone-I and Agro Ecological Situation-I having total 172366 ha land. Out of that, $53.74 \%$ is occupied with forest and only $33.80 \%$ of land comes under cultivated and cultivable fallow. The district is remote forest area and characterized mainly by tribals. Soils of the area under study were lateritic, shallow to medium in depth, low to moderately fertile, medium to high in slope, normal to slightly acidic $\mathrm{pH}$ and the average annual rainfall of this area is 1800 to $2000 \mathrm{~mm}$ with 85 to 95 average rainy days (Anonymous, 2014). The critical inputs like chemical fertilizers (Urea, SSP and MoP), biofertilizers (Azotobacter, PSB and KMS) and manures (vermi 
compost) were provided from the KVK along with trainings on all the recommended package of practices of NAU, Navsari like suitable varieties (YVMV tolerant), plant spacing $(45 \times 30$ $\left.\mathrm{cm}^{2}\right)$, paired row planting $\left(30 \times 30 \times 60 \mathrm{~cm}^{3}\right)$, seed rate $(5 \mathrm{~kg} \mathrm{ha}$ $\left.{ }^{1}\right)$ recommended dose of fertilizers (150:50:50 kg NPK ha-1), biofertilizers (2 liters ha ${ }^{-1}$ ), application of FYM (15-20 t ha-1) and vermi compost, use of bio control agents (Trichoderma \& Pseudomonas), drip irrigation, mulching (25-30 micron black polyethylene plastic film) and integrated pest, disease \& weed management practices (growing marigold as trap crop, spraying of neem based insecticide, use of yellow sticky cards, pheromone traps and timely management). Field days were also conducted in each cluster to show the results of front line demonstration to the farmers of the same and neighbouring villages. The data on yield and returns were collected by KVK, scientists with frequent field visits during 2012-13 to 2014-15 from front line demonstration and farmer's practices plots and finally extension gap, technology gap, and technology index were calculated as given by Samui et al. (2000) as follow. The details of numbers and area of demonstrations along with farming situation during the period of the study are presented in Table 1.

Demonstration yield-

Per cent increase in yield $=\frac{\text { Farmers practice yield }}{\text { Farmers practice } \text { yield }} \times 100$ Benefit: Cost Ratio $=\frac{\text { Gross return }}{\text { Cost of cultivation }}$

Technology gap=Potential yield- Demonstration yield

Extension gap=Demonstration yield-Yield under farmer's practice

Technology index $=\frac{\text { Potential yield-Demonstration yield }}{\text { Potential yield }} \times 100$

\begin{tabular}{|c|c|c|c|c|c|c|c|c|c|c|c|c|c|}
\hline \multirow[t]{2}{*}{ Crop } & \multirow[t]{2}{*}{$\begin{array}{l}\text { Season/ } \\
\text { Year }\end{array}$} & \multirow{2}{*}{$\begin{array}{l}\text { No. of } \\
\text { farm- } \\
\text { ers }\end{array}$} & \multirow[t]{2}{*}{$\begin{array}{l}\text { Area } \\
\text { (ha) }\end{array}$} & \multirow[t]{2}{*}{$\begin{array}{l}\text { Farming } \\
\text { situation }\end{array}$} & \multirow[t]{2}{*}{$\begin{array}{l}\text { Soil } \\
\text { type }\end{array}$} & \multicolumn{3}{|c|}{$\begin{array}{c}\text { Status of } \\
\text { soil }\end{array}$} & \multirow{2}{*}{$\begin{array}{l}\text { Previ- } \\
\text { ous } \\
\text { crop }\end{array}$} & \multirow[t]{2}{*}{ Sowing date } & \multirow[t]{2}{*}{$\begin{array}{c}\text { Harvest } \\
\text { date }\end{array}$} & \multirow{2}{*}{$\begin{array}{l}\text { Sea- } \\
\text { sonal } \\
\text { rainfall } \\
(\mathrm{mm})\end{array}$} & \multirow{2}{*}{$\begin{array}{c}\text { No. of } \\
\text { rainy } \\
\text { days }\end{array}$} \\
\hline & & & & & & $\mathrm{N}$ & $P$ & $\mathrm{~K}$ & & & & & \\
\hline Okra & $\begin{array}{l}\text { Rabi, } \\
\text { 2012-13 }\end{array}$ & 10 & 5.0 & Irrigated & $\begin{array}{c}\text { Lateritic } \\
\text { black }\end{array}$ & $\mathrm{L}$ & $\mathrm{M}$ & $\mathrm{H}$ & Paddy & $\begin{array}{l}\text { 2nd week of } \\
\text { Nov., } 2012\end{array}$ & $\begin{array}{l}\text { 2nd week of } \\
\text { April, } 2013\end{array}$ & 3203 & 91 \\
\hline Okra & $\begin{array}{l}\text { Rabi, } \\
\text { 2013-14 }\end{array}$ & 10 & 5.0 & Irrigated & $\begin{array}{c}\text { Lateritic } \\
\text { black }\end{array}$ & $\mathrm{H}$ & $\mathrm{M}$ & $\mathrm{H}$ & Paddy & $\begin{array}{l}\text { 1st week of } \\
\text { Nov., } 2013\end{array}$ & $\begin{array}{l}\text { 1st week of } \\
\text { April, } 2014\end{array}$ & 2038 & 60 \\
\hline Okra & $\begin{array}{l}\text { Rabi, } \\
\text { 2014-15 }\end{array}$ & 10 & 5.0 & Irrigated & $\begin{array}{c}\text { Lateritic } \\
\text { black }\end{array}$ & $\mathrm{H}$ & $\mathrm{M}$ & $\mathrm{H}$ & Paddy & $\begin{array}{l}\text { 4th week of } \\
\text { Nov., } 2014\end{array}$ & $\begin{array}{l}\text { 4th week } \\
\text { of March, } \\
2014\end{array}$ & 1658 & 50 \\
\hline
\end{tabular}

\section{Results and Discussion}

The data with respect to yield and economic returns are presented in Table-2, whereas the data pertaining to extension gap, technology gap and technology index are presented in Table 3.

\subsection{Yield}

The results revealed that due to front line demonstration on okra, yield ranged from 94.0 to $98.0 \mathrm{q} \mathrm{ha}^{-1}$ in demonstration

Table 2: Yield and economic impact of FLDs on INM in okra in the Dang district of Gujarat

\begin{tabular}{|c|c|c|c|c|c|c|c|c|c|c|c|c|c|c|c|}
\hline \multirow[t]{3}{*}{ Year } & \multirow[t]{3}{*}{ NF } & \multirow[t]{3}{*}{$\begin{array}{l}\text { Area } \\
\text { (ha) }\end{array}$} & \multicolumn{3}{|c|}{ Yield (q ha-1) } & \multirow[t]{3}{*}{ LC } & \multirow[t]{3}{*}{$\begin{array}{l}\mathrm{CY} \\
\%\end{array}$} & \multicolumn{4}{|c|}{$\begin{array}{l}\text { Economics of demonstration } \\
\qquad\left(₹ \mathrm{ha}^{-1}\right)\end{array}$} & \multicolumn{4}{|c|}{$\begin{array}{c}\text { Economics of farmer's practices } \\
\text { (local-check) (₹ ha-1) }\end{array}$} \\
\hline & & & \multicolumn{3}{|c|}{ Demo } & & & \multirow{2}{*}{$\begin{array}{l}\text { Gross } \\
\text { Cost }\end{array}$} & \multirow{2}{*}{$\begin{array}{l}\text { Gross } \\
\text { Return }\end{array}$} & \multirow{2}{*}{$\begin{array}{l}\text { Net } \\
\text { Return }\end{array}$} & \multirow[t]{2}{*}{ BCR } & \multirow{2}{*}{$\begin{array}{l}\text { Gross } \\
\text { Cost }\end{array}$} & \multirow{2}{*}{$\begin{array}{l}\text { Gross } \\
\text { Return }\end{array}$} & \multirow{2}{*}{$\begin{array}{l}\text { Net } \\
\text { Return }\end{array}$} & \multirow[t]{2}{*}{$\mathrm{BCR}$} \\
\hline & & & High & Low & Ave. & & & & & & & & & & \\
\hline $\begin{array}{l}2012- \\
13\end{array}$ & 10 & 5.0 & 98.0 & 90.0 & 94.0 & 85.0 & 10.6 & 41000 & 98000 & 57000 & 2.40 & 35000 & 68210 & 33210 & 1.95 \\
\hline $\begin{array}{l}2013- \\
14\end{array}$ & 10 & 5.0 & 100.0 & 89.0 & 96.0 & 84.0 & 14.3 & 42500 & 115200 & 72700 & 2.71 & 38200 & 100800 & 62600 & 2.64 \\
\hline $\begin{array}{l}2014- \\
15\end{array}$ & 10 & 5.0 & 102.0 & 90.0 & 98.0 & 82.0 & 19.5 & 43200 & 127400 & 84200 & 2.95 & 38700 & 106600 & 67900 & 2.75 \\
\hline $\begin{array}{l}\text { Aver- } \\
\text { age }\end{array}$ & -- & -- & 100.0 & 89.7 & 96.0 & 83.7 & 14.8 & 42233 & 113533 & 71300 & 2.69 & 37300 & 91870 & 54570 & 2.45 \\
\hline
\end{tabular}

NF: No. of farmers; LC: Local check; CY: \% change in Yield 


\begin{tabular}{|c|c|c|c|c|c|c|}
\hline Years & $\begin{array}{c}\text { Potential yield } \\
\quad\left(q \text { ha }^{-1}\right)\end{array}$ & $\begin{array}{l}\text { Ave. Demonstra- } \\
\left.\text { tion yield ( } \mathrm{q} \mathrm{ha}{ }^{-1}\right)\end{array}$ & $\begin{array}{l}\text { Farmer's practices } \\
\left.\text { (local) yield (q ha }{ }^{-1}\right)\end{array}$ & $\begin{array}{l}\text { Extension gap } \\
\qquad\left(q \text { ha }^{-1}\right)\end{array}$ & $\begin{array}{l}\text { Technology } \\
\text { gap (q ha-1) }\end{array}$ & $\begin{array}{l}\text { Technology } \\
\text { index (\%) }\end{array}$ \\
\hline $2012-13$ & 120 & 94.0 & 85.0 & 9.0 & 26.0 & 21.7 \\
\hline 2013-14 & 120 & 96.0 & 84.0 & 8.0 & 24.0 & 20.0 \\
\hline 2014-15 & 120 & 98.0 & 82.0 & 16.0 & 22.0 & 18.3 \\
\hline Average & 120 & 96.0 & 83.7 & 11.0 & 24.0 & 20.0 \\
\hline
\end{tabular}

plots and from 82.0 to $85.0 \mathrm{q} \mathrm{ha}^{-1}$ in farmer's practice plot in three years of demonstration (Table 2). An average yield of $96.0 \mathrm{q} \mathrm{ha}^{-1}$ was obtained under demonstration plots as compared to $83.7 \mathrm{q} \mathrm{ha}^{-1}$ in farmer's practices plots during the three years. This results clearly indicated that the higher average yield in demonstration plots over the years compare to farmers practice may be due to knowledge and adoption of full package of practices i.e. use of recommended dose of fertilizers through INM, bio fertilizer, vermicompost, and timely application of plant protection chemicals. Similar results were also reported by Kalalbandi et al. (2006) in chilli crop as well as by Dhemre and Desale (2010) in okra crop. The increment in yield ranged between 10.6 to $19.5 \%$ and the three years average increase in yield of okra was $14.8 \%$. The above findings are in similarity with the findings of Balai et al. (2013) and Singh et al. (2011) in vegetable crops. However variations in the yield of okra in different years might be due to the variations in environmental factors like soil fertility, moisture availability, rainfall, etc, and the change in the location of demonstrations every year.

\subsection{Economic returns}

The input and output prices of commodities prevailed during the study of demonstrations were taken for calculating cost of cultivation, gross return, net return and benefit: cost ratio and the data is presented in Table 2. The cultivation of okra under INM and other improved technologies gave higher net return of ₹ $57,000.00 \mathrm{ha}^{-1}$, ₹ $72,700.00 \mathrm{ha}^{-1}$ and ₹ $84,200 \mathrm{ha}^{-1}$ during the years 2012-13, 2013-14 and 2014-15, respectively with an average net return of ₹ $71,300.00 \mathrm{ha}^{-1}$ which was higher as compared to farmer's practices ( $\left.₹ 54,570.00 \mathrm{ha}^{-1}\right)$. The benefit cost ratio of okra ranged from 2.40 to 2.95 in demonstration plots and from 1.95 to 2.75 in farmer's practice plots during three years of demonstration with an average of 2.69 in demonstration and 2.45 under farmer's practices. This may be due to higher yield obtained under improved technologies as compared to local check (farmers practice). This finding is similar with the findings of Singh et al. (2011) in solanaceous vegetables and Shalini et al. (2016) in tomato.

\subsection{Extension gap}

Extension gap of 9.0, 8.0 and $16.0 \mathrm{q} \mathrm{ha}^{-1}$ was observed during the years 2012-13, 2013-14 and 2014-15, respectively (Table 3). On an average extension gap under three year FLD programme was $11.0 \mathrm{q} \mathrm{ha}^{-1}$. This emphasized the need to educate the farmers through various techniques for the adoption of improved agricultural production technologies to reverse this trend of extension gap. More and more use of latest production technologies with high yielding variety will subsequently change this alarming trend of galloping extension gap (Teggelli et al., 2015 in pigeon pea).

\subsection{Technology gap}

The technology gap, that is the differences between potential yield and yield of demonstration plots was 26.0, 24.0 and $22.0 \mathrm{q} \mathrm{ha}^{-1}$ during the years 2012-13, 2013-14 and 2014-15, respectively (Table 3). On an average technology gap under three year FLD programme was $24 \mathrm{q} \mathrm{ha}^{-1}$. This may be due to the variations in soil fertility, managerial skills of individual farmer's and climatic conditions of the area. Hence, location specific recommendations are necessary to bridge this gap (Singh et al., 2011 in solanaceous vegetables).

\subsection{Technology index}

The technology index shows the feasibility of the demonstrated technology at the farmer's field. The technology index varied from 18.3 to 21.7 (Table 3). On an average technology index of $20.0 \%$ was observed during the three years of FLD programme, which shows the effectiveness of technical interventions. This accelerates the adoption of demonstrated technical interventions to increase the yield performance of okra.

\section{Conclusion}

The FLD produced a significant positive result and provided an opportunity to demonstrate the productivity potential and profitability of the latest technology (intervention) under the real farming situation. By conducting demonstrations of INM and improved scientific technologies, yield potential of okra can be increased to a great extent. This will substantially increase the income as well as the livelihood of the farming community. There is a need to adopt multi-pronged strategy that involves enhancing okra production through improved technologies in Dang district of Gujarat state.

\section{References}

Anonymous, 2014. Annual Progress Report of KVK, NAU, Waghai for the year 2014-15, 4-5.

Balai, C.M., Jalwania, R., Verma, L.N., Bairwa, R.K., Regar, P.C., 2013. Economic impact of front line demonstrations on vegetables in tribal belt of Rajasthan. Current 
Agriculture Research Journal 1(2) 69-77.

Dhemre, J.K., Desale, S.B., 2010. Impact of front line demonstration on production technology of okra cv. "Phule Utkarsha" in Dhule district of Maharashtra. Asian Scientific 5(1), 29-31.

Kalalbandi, B.M., Dudhate, D.G., More, S.S., 2006. Impact of front line demonstration on chilli (Capsicum annum L.) production technology in Parbhani district of Maharashtra state. Crop Protection 3(1), 157-158.

Samui, S.K., Mitra, S., Roy, D.K., Mandal, A.K., Saha, D., 2000. Evaluation of front line demonstration on groundnut. Indian Society of Coastal Agricultural Research 18 (2), 180-183.

Shalini, M., Devaraja, Gowda, M., 2016. Impact of front line demonstrations on yield and economics of tomato in Chikkaballapur district of Karnataka. International
Journal of Applied and Pure Science and Agriculture, 2 (7), 4-8.

Singh, R., Soni, R.L., Singh, V., Bugalia, H.L., 2011. Dissemination of improved production technologies of solanaceous vegetables in Banswara district of Rajasthan through Frontline demonstrations. Rajasthan Society of Extension Education 19, 97-100.

Teggelli, R.G., Patil, D.H., Naik, A., Zaheer Ahamed, B., Patil, M.C., 2015. Impact of frontline demonstration on the yield and economics of pigeon pea in Kalaburgi district of Karnataka state. International Journal of Science and Nature 6(2), 224-227.

Yawalkar, K.S., Ram, H.H., 2004. Fruit Vegetables. In: Vegetable crops of India Eds, Nagpur: Agri-Horticultural Publishing House, 99-112. 